
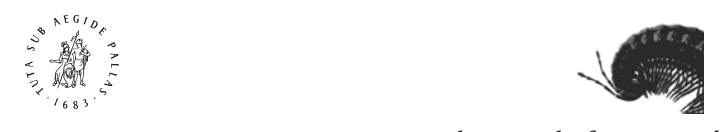

B R I L L

International Journal of Myriapodology 3 (2010) 19-24

\title{
Welcome back, Ancylochetus! (Polydesmida: Chelodesmidae: Prepodesminae)
}

\author{
Richard L. Hoffman \\ Virginia Museum of Natural History, 21 Starling Avenue, Martinsville, Virginia 24112, USA \\ E-mail: richard.hoffman@vmnh.virginia.gov
}

\begin{abstract}
The prepodesmine genus Ancylochetus, undocumented since its original proposal in 1931, is revised from specimens of the type species, A. signatus Attems. The course of the prostatic groove is clarified, and relationships of the genus examined.
\end{abstract}

Key words

Ancylochetus, Chelodesmidae, Prepodesminae, gonopod structure, Nigeria

\section{Introduction}

The new generic name Ancylochetus was proposed by Count Attems in 1931 to accommodate the new species signatus, the type material of which being attributed to " $\mathrm{Li}$ beria: Ölflusse". An abridged version of the original account was printed subsequently in Attems' treatment of prepodesmines in the "Tierreich" series (1938), and the genus was included incidentally in listings of these animals by Chamberlin (1952), Demange \& Mauriès (1975), and myself (1980). Our knowledge of this rather neglected taxon therefore consists solely of its eighty-year old original description. The opportunity to review the genus in a modern context is provided by examination of numerous specimens of the type species from two localities in the Niger delta.

Although Attems' description and illustrations clearly portrayed those traits that he considered of generic significance, he failed to provide a diagnostic statement, per se, contrasting Ancylochetus with other genera of the group he knew as "Cordyloporinae". Only by reference to his key to these nine taxa do we find a definitive indication in couplet 4 to the effect that the loop formed by the prostatic groove prior entering onto 
the very short tibiotarsus is what distinguishes Ancyclochetus. This singular condition was shown by dotted lines in Attems' Fig. 140 which explains his use of Schleife (a loop or bow) as well as the formation of the generic name (ankylos, Gk., hooked or bent). Although the gonopod drawings are remarkably accurate to have been made from a microscope preparation - which denied the possibility of examination from several different aspects - Fig. 140 lacks the single detail that would explain how a surface groove could cross over itself twice.

The type material appears not to exist, at least searches by myself and museum staff at both Hamburg and Vienna have been unsuccessful. Nonetheless, Attems' description and drawings agree so precisely with the specimens at hand, I think there can be no doubt of their identity.

\section{Taxonomy}

\section{Family Chelodesmidae Cook}

\section{Subfamily Prepodesminae Cook}

\section{Genus Ancylochetus Attems}

Ancylochetus Attems, 1931, Zoologica, Stuttgart 79: 96. Monobasic with a new species. Type species, Ancylochetus signatus Attems by monotypy and original designation.

Diagnosis: Sternum of $4^{\text {th }}$ segment of males with two prominent acutely conical processes, $5^{\text {th }}$ sternum with similar but smaller processes. Gonopods without median sternal sclerite; coxae elongate, subcylindrical, without apophysis, tracheosternal apodeme slender, not recurved. Telopodite robust, set on coxa at right angle, setose (?prefemoral) region about half of telopodite length, set off from acropodite element by defined groove on ventral side and shallow depression on mesal; acropodite with two large components: the laterally placed primary lamina which carries the prostatic groove and a slender falcate basal process, and the more mesial, apically trilobed secondary process. Cyphopods large, the posterior valves large and setose, nearly in contact mesially, much larger than anterior and incrassate, receptacle and operculum small and obscure.

Distribution: This monotypic genus remains known only from the southern edges of the Niger River delta, Nigeria.

Species: One.

Relationships: Attems did not offer any opinion about possible affinities of his genus. The "arrangement" proposed by Chamberlin in 1952, which only arranged prepodesmine genera alphabetically within the two subfamilies he recognized, was not very helpful. Demange \& Mauriès (1975: 139) suggested that the genus appeared to be close to Paracordyloporus, but did not provide a key to the genera referred by them 
to the subfamily Cordyloporinae. Examination of the unmounted gonopods allows a better perspective of these appendages but does not shed much light on the subject of relationships. In a general way the telopodites resemble those in the regional genus Afolabina, in that the prostatic groove is carried by a wide flattened structure rather than a flagelliform solenomere. By broadening and folding this branch on itself, one could achieve an effect similar to the structure occurring in A. signatus. In my view, the gonopod in Paracordyloporus is sufficiently distinctive to preclude a convincing relationship of that genus with Ancylochetus.

\section{Ancylochetus signatus Attems}

Figs 1-9

Ancylochetus signatus Attems, 1931, Zoologica Stuttgart 67: 97, figs. 138-140. Three syntypes (location, if extant, unknown) from "Liberia: Ölflusse" (recte: Nigeria). Ancylochetus signatus: Attems 1938, Das Tierreich 69: 394, fig. 431. - Chamberlin 1952, J. Washington Acad. Sci. 42: 00. - Demange \& Mauriès 1975, Ann. Mus. Royal Afr. Centr., ser. zool. 212: 139.

Material examined: Nigeria: Rivers State, Rumuckwuta, Port Harcourt (4.50N, 6.59E), June 1979, C. B. Powell, male and two females, all highly fragmented. - Cross Rivers State: "vicinity [= $90 \mathrm{~km}$ radius] of Calabar, 1982" J. C. Reid, two males, four females; ca $22 \mathrm{~km}$ northeast of Calabar, 11-12 May 1983, J. C. Reid, one male; Ayip Eka palm plantation, 5.28N, 8.42E, 6 November 1980, J. C. Reid, one male (all VMNH).

Male (Calabar): Decolored, fragmented. Length ca. $44 \mathrm{~mm}$, body narrowest anteriad, widening back to midlength: segment $5,5.7 \mathrm{~mm}$; segments $9-13,6.1 \mathrm{~mm}$, segment $15,5.9 \mathrm{~mm}$.

Coloration (translated from Attems 1931): dark brown, almost blackish-brown, lateral corners of paranota of segments 1-4 reddish-yellow in males, only of the $2^{\text {nd }}$ segment in females; poriferous paranota reddish-yellow, extended mediad over much of the metaterga; antennae and legs dark reddish-brown.

Labroclypeal region densely setose, interantennal and epicranial surfaces only sparsely so. Labrogenal offset prominent. Antennae long $(8.0 \mathrm{~mm})$ and slender, antennomeres not clavate. Collum transversely ovoid with lateral ends symmetrically narrowed. Paranota of segments 2-5 directed anteriad, (Fig. 1), the anterior corners acute; both corners rounded on segments 7-11, thereafter posterior becoming increasingly more produced. Ozopores placed near midlength of elongate peritremata, these set off from lateral edge by small indentations back to $16^{\text {th }}$ segment, thereafter merged entirely with edge. All paranota set high on sides and nearly horizontal. Metaterga uniformly and finely granulate, with distinct sulcus on segments 3-17, no transverse series of tubercles nor areolation evident. Lateral subterminal tubercles of epiproct acute, prominent. Edge of hypoproct evenly arcuate, no median projection or paramedian tubercles evident. Stricture evident around body but without sharp demarcation. Sides 
of metazona mostly smooth or finely granulose, typically with a single large acutely conical spine above posterior coxa, some segments with a few smaller spines placed more dorsad. Stigmata small and narrow, vertically elongated, largest dorsally and contiguous to coxal condyles. Sterna ca $1.5 \mathrm{~mm}$ wide at midbody, slightly elevated above level of prozona, setose, without subcoxal spines. Legs long (increasing in length to 9.5 $\mathrm{mm}$ on posterior segments) with slender, sparsely setose, unmodified podomeres.

Sternum of $4^{\text {th }}$ segment (Fig. 3) with two acutely conical paramedian processes, sternum of $5^{\text {th }}$ segment with smaller, subcoxal projections. Sternum of segment 6 un-
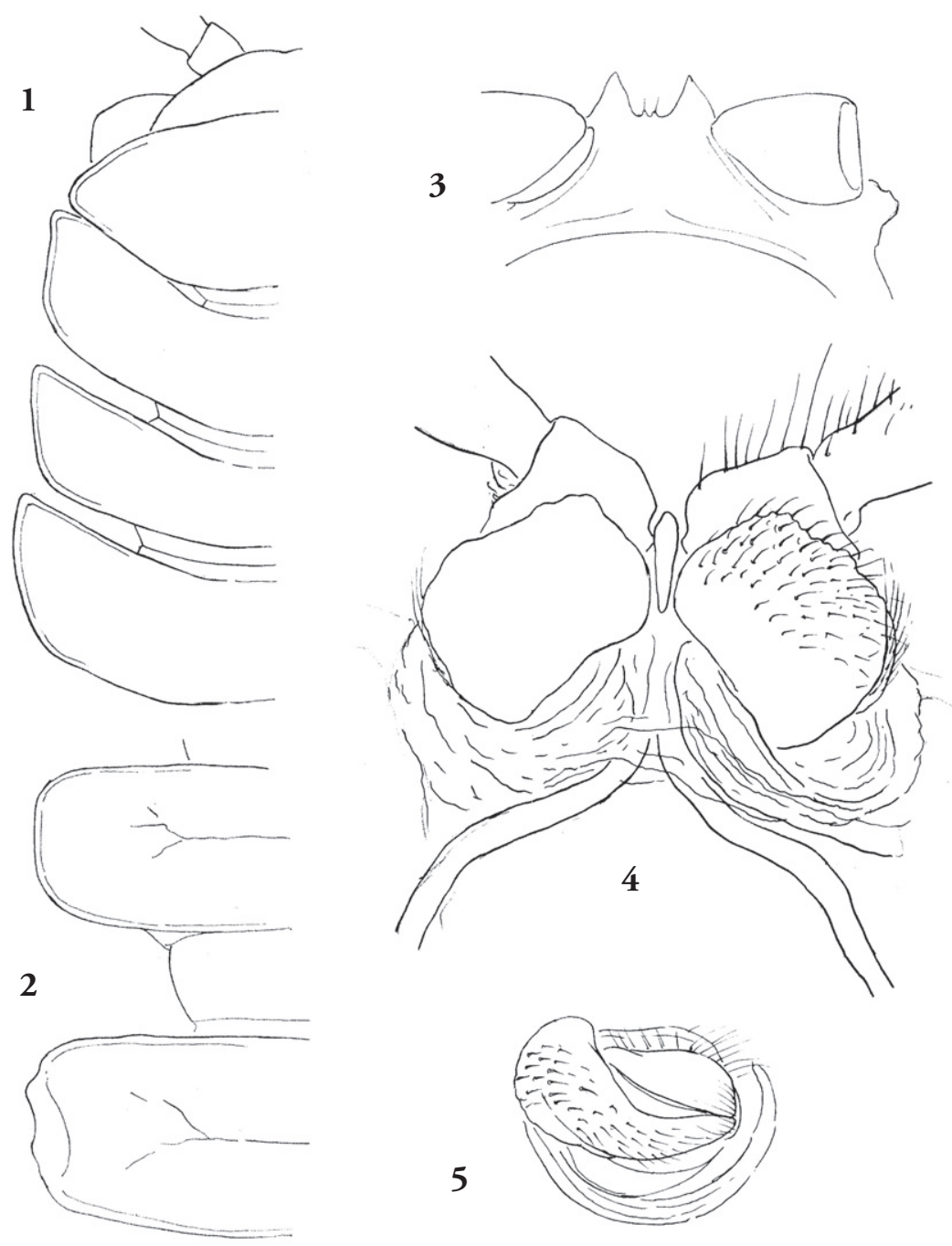

Figures 1-5. Ancylochetus signatus Attems, structural details. 1. Left side of head and paranota of body segments 1-4, dorsal aspect. 2. Left paranota of segments 8 and 9, dorsdal aspect. 3. Sternum and leg bases of $4^{\text {th }}$ segment, posterior aspect. 4. Cyphopods and bases of $3^{\text {rd }}$ leg pair, posterior aspect. 5. Right cyphopod, distal aspect, showing hypertrophy of posterior valve. 
modified. Gonopod aperture of $7^{\text {th }}$ segment ovoid, only slightly displacing stricture and metasternum, lateral ends slightly elevated.

Gonopods as described under generic heading and illustrated in Figs 6-9, notable in that the prostatic groove is carried along the mesal edge of the primary telopodite dorsal flange (PL), at the end of which it curves over onto a closely appressed, more internal, flange thence recurves proximad before proceeding onto the long, very slender solenomere (S) projecting from the inner flange (Fig. 9), subtended by an adjacent linear process (parasolenomere, $\mathrm{P}$ ).
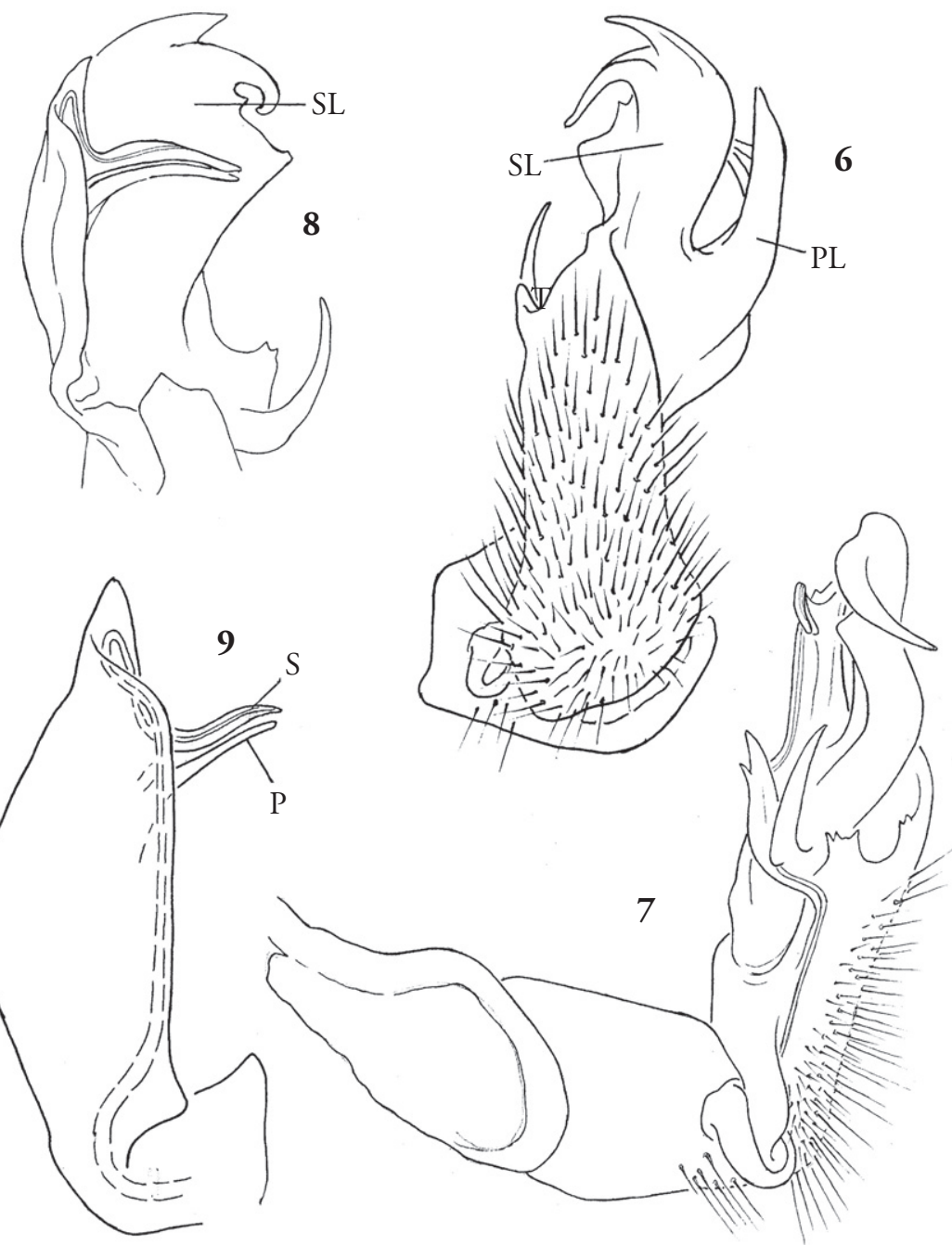

Figures 6-9. Ancylochetus signatus Attems, male gonopods. 6. Left gonopod in situ, ventral aspect. 7. Left gonopod, mesal aspect. 8. Telopodite of left gonopod, dorsal aspect. 9. Primary lamina of telopodite, dorsal aspect enlarged to show course of prostatic groove. Abbreviations: P, parasolenomere, PL, primary lamina of acropodite, S, solenomere, SL, secondary lamina of acropodite. 
Female (Calabar): Length ca. $42 \mathrm{~mm}$ (fragmented), width segment 5, $5.9 \mathrm{~mm}$, segments 9-13, $6.5 \mathrm{~mm}$, segment 15, $6.3 \mathrm{~mm}$. Generally similar to male except for slightly greater body size, smaller paranota, and broader sterna. Metasternal region of $3^{\text {rd }}$ segment thin, not flared or elevated, most of cyphopods readily visible in situ. Sclerotized elements of cyphopods (Fig. 4) large, conspicuous, basally surrounded by pleated membrane possibly capable of extrusion, receptacle and operculum only slightly sclerotized and difficult to distinguish from adjacent membrane. Posterior (medial?) valve (distal aspect, Fig. 5) notably enlarged anteromesad and much larger than the anterior (lateral); operculum small, flat, inconspicuous. Coxae and other podomeres of $2^{\text {nd }}$ legpair of normal polydesmoid size and shape, without modifications.

Commentary: Attribution of the type locality to Liberia is of course erroneous, as the German place name "Ölflusse" (Oil River) refers to the lower reaches of the Niger River delta, and derives from the former abundance of oil palm plantations. The subsequent development of that region for extraction of a different kind of oil (petroleum) is an interesting coincidental sequel.

\section{Acknowledgements}

I am indebted to Drs. C. B. Powell and J. C. Reid for donating the specimens reported here, and to Drs. H. Dastych (Hamburg) and Verena Stagl (Vienna) for information about the status of the type material of $A$. signatus. The original pencil renditions of the illustrations were prepared by Emily Kohler (Martinsville).

\section{References}

Attems, C. (1931) Die Familie Leptodesmidae und anderen Polydesmiden. - Zoologica (Stuttgart) 30 (79): 1-150.

Attems, C. (1938) Myriapoda 3, Polydesmidea II, Fam. Leptodesmidae, Platyrhachidae, Oxydesmidae, Gomphodesmidae. - Das Tierreich 69: 1-487.

Chamberlin, R. V. (1952) An arrangement of the Prepodesmidae, a family of African millipeds. - Journal of the Washington Academy of Sciences 42: 327-333.

Demange, J.-M., \& Mauriès J.-P. (1975) Myriapodes-Diplopodes des Monts Nimba et Tonkoui (Côte d'Ivoire, Guinée) récoltés par M. Lamotte et ses collaborateurs de 1942 à 1960. Étude systématique, Caractérisation des Diopsiulides africains, Révision des Trachystreptini, Essai de classification des Cordyloporidae. - Annales du Musée Royale de l'Afrique Centrale, Serie in- $8^{\circ}-$ Sciences Zoologiques 212: 1-192.

Hoffman, R. L. (1980) Classification of the Diplopoda. Museum d'Histoire Naturelle, Genève, $237 \mathrm{pp}$. 